\title{
FIRST RECORD OF LEBETUS GUILLETI (ACTINOPTERYGII: PERCIFORMES: GOBIIDAE) FROM THE SEA OF MARMARA
}

\author{
Semih ENGIN *, Tolga AKDEMIR, and Arif Can KESKIN \\ Faculty of Fisheries, Izmir Katip Celebi University, Turkey
}

Engin S., Akdemir T., Keskin A.C. 2015. First record of Lebetus guilleti (Actinopterygii: Perciformes: Gobiidae) from the Sea of Marmara. Acta Ichthyol. Piscat. 45 (1): 85-87.

\begin{abstract}
A single specimen of the Guillet's goby, Lebetus guilleti (Le Danois, 1913), was collected and photographed during a gobiid fish survey by scuba diving from the Sea of Marmara. The fish measured $12.1 \mathrm{~mm}$ (standard length). This finding constitutes the first record of L. guilleti from the Sea of Marmara and the fourth from the Mediterranean Sea.
\end{abstract}

Keywords: Guillet's goby, smallest gobiid fish, scuba diving

The smallest European marine fish known as the Adriatic Sea (Herler and Kovačić 2002). Hope and Guillet's goby, Lebetus guilleti (Le Danois, 1913), is one of Shucksmith (2010) listed Scotland as the northernmost the most infrequent gobiid species in the Mediterranean Sea. part of this species' range. Lebetus guilleti has never been Guillet's goby inhabits stone-, shell-, coralligenous-, and, recorded from the eastern part of the Mediterranean basin gravelly substrates at a depth range of 2-30 m (Miller 1986, (Golani et al. 2006, Fricke et al. 2007).

Herler and Kovačić 2002, Hope and Shucksmith 2010). The presently reported finding of L. guilleti from the In the Mediterranean Sea, this goby has been recorded Sea of Marmara constitutes its first record from the northfrom Banyuls (Miller 1990) and the northern part of the eastern part of the Mediterranean Sea (Fig. 1).

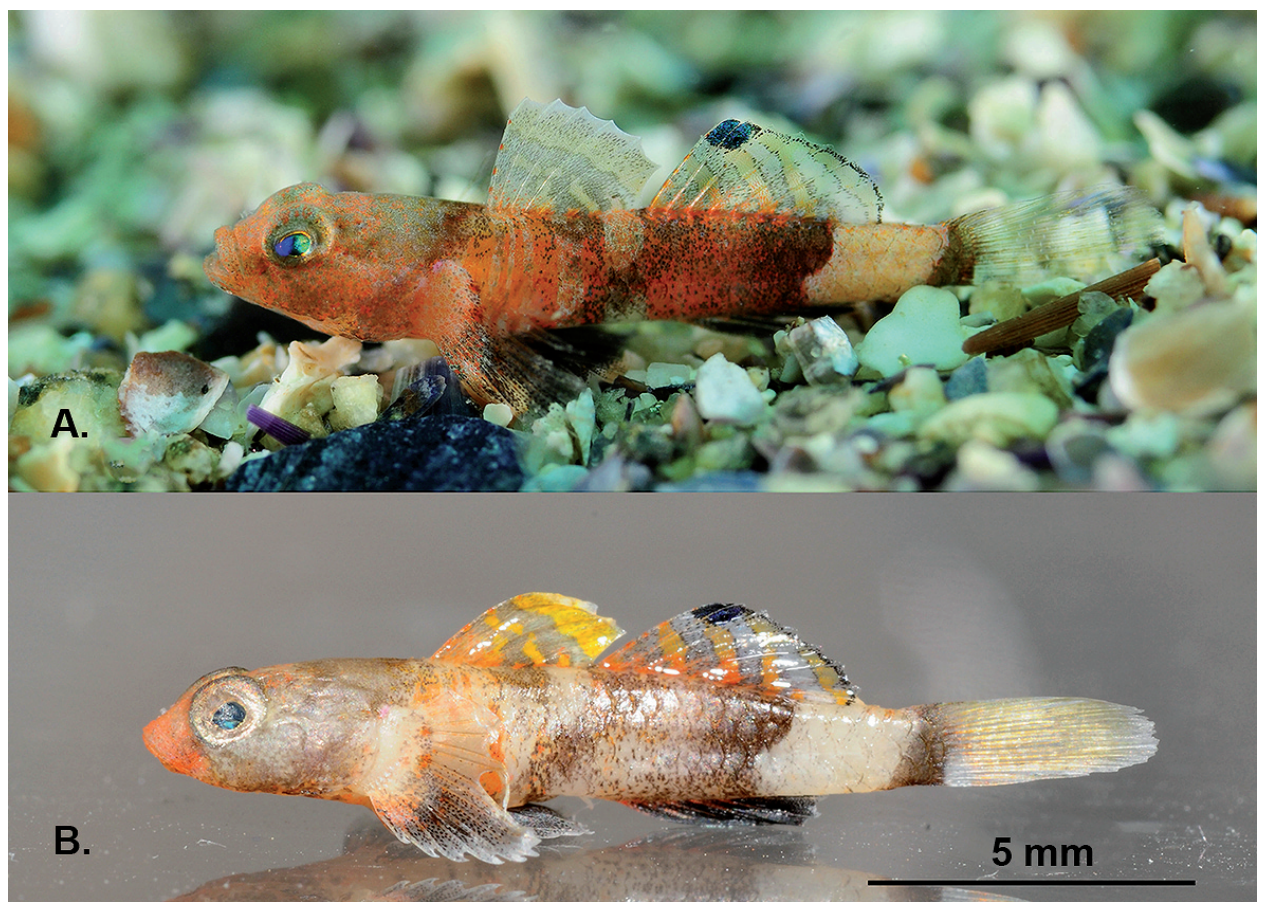

Fig. 1. Lebetus guilleti; (A) in its natural habitat, (B) five days after fixation; photographed by Semih Engin

\footnotetext{
${ }^{*}$ Correspondence: Semih Engin, İzmir Kâtip Çelebi Üniversitesi, Su Ürünleri Fakültesi, Balıkçılık Temel Bilimler Bölümü, Çiğli Ana Yerleşkesi, 35620 İzmir, Turkey,
} phone: +90 (232) 325 40 40, fax: 023238608 88, e-mail: (SE) engin.semih@gmail.com, (TA) tolgaakdemir@gmail.com(ACK) karadenizarsiv@gmail.com. 
A single specimen of Lebetus guilleti (Fig. 1) was collected at Ilhan Koy (Erdek) - Horkos Island (40 $31^{\prime} 27^{\prime \prime} \mathrm{N}$, $\left.27^{\circ} 42^{\prime} 27^{\prime \prime} \mathrm{E}\right)$ (Sea of Marmara) (Fig. 2) in June 2014 during an underwater survey carried out by three scuba divers. The fish obtained this way was anaesthetized with quinaldine and fixed in $\% 4$ formaldehyde solution. The collected specimen was deposited in the Marine Museum of the İzmir Kâtip Çelebi University (IKCMM - PIS/05-2014). Species identification, solely based on morphological characters was aided by descriptions provided by Miller (1986) and Herler and Kovačić (2002).

The collected specimen of Lebetus guilleti was determined based on the following features: Small body size, specific body coloration, complete loss of the head lateral line canals, presence of suborbital row $a$, limited number of head sensory papillae with two interorbital rows and meristic values of D2 (second dorsal fin), A (anal fin), P (pectoral fin), LL (scales in lateral series). Head small, eyes are larger than snout. No head canals. Anterior nostril short, predorsal area and head naked. Meristic features of Guillet's goby are compared in Table 1 with those determined by Herler and Kovačić (2002).

The sampled male specimen of Lebetus guilleti exhibited unique coloration. The nape was grey with orange dots and these dots were more intensive around the cheeks. The lateral side of trunk had five vertical grey bands below the first dorsal fin. The first three grey bands were narrow while the other ones were wider. The coloration among grey bands was orange. The other part of the trunk under the second dorsal fin was orange and was separated with $\mathrm{S}$-shaped border from the white caudal peduncle. The base of caudal fin had darker coloration. The trunk was covered with irregular small black dots. Three pale yellow stripes on first dorsal fin and the upper edge were whitish. The second dorsal fin had 5-6 diagonal pale yellow stripes. A flashily navy blue blotch was located between upper part of first and third rays of second dorsal fin. Caudal fin was transparent. Anterior part of pectoral fin was grey with orange and black dots. Pelvic and anal fins were covered with intensive black dots.

The specimen lost quickly orange coloration after fixation but the stripes on the dorsal fins became distinctly orange. The mouth maintained the orange coloration. The observed body coloration of the presently described specimen of Lebetus guilleti is consistent with the description given by Herler and Kovačić (2002) and Hope and Shucksmith (2010).

The bottom where the fish was captured was a coarse substrate containing biogenic calcareous fragments and shell gravel with coralline deposits. The site was partially distant from the coastal sedimentation.

In our survey one male specimen of Lebetus guilleti (15.6 mm TL, $12.1 \mathrm{~mm} \mathrm{SL}$ ) was sampled at a depth of $22 \mathrm{~m}$ while Herler and Kovačić (2002) collected their specimens at 6-13 m. Another female specimen was observed at $18 \mathrm{~m}$ depth but could not be caught because of the reduced visibility created by the halocline layer. This layer was observed between 18-25 $\mathrm{m}$ depth and the salin-

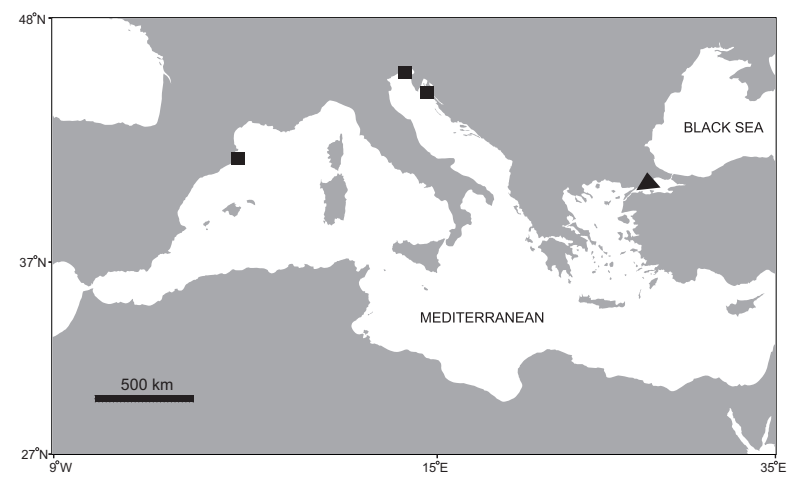

Fig. 2. Distribution of the Lebetus guilleti in the Mediterranean; - Previous records (left to right, respectively): Banyuls, France; Rovinj and Kvarner region, Croatia $\boldsymbol{\Delta}$ Presently reported new record from the Sea of Marmara

Table 1

Meristic features of Lebetus guilleti

\begin{tabular}{lcc}
\hline Character & PRS & H\&K \\
\hline D2 & I/8 & I/7-8 \\
A & $1 / 5$ & $1 / 4-5$ \\
P & 15 & $14-15$ \\
LL & 25 & $24-26$ \\
\hline
\end{tabular}

PRS $=$ Presently reported study, H\&K = Herler and Kovačić 2002, D2 = second dorsal fin, $\mathrm{A}=$ anal fin, $\mathrm{P}=$ pectoral fin, $\mathrm{LL}=$ scales in lateral series.

ity was $39 \%$ under the halocline while it was $23 \%$ above it. Possibly halocline acts as an ecological barrier for L. guilleti prohibiting the species to dwell at shallower depths (above $18 \mathrm{~m}$ ) where salinity is lower.

During the same survey other gobiid species were observed from different depths in the sampling location. Those species were: Gobius auratus Risso, 1810; Gobius niger Linnaeus, 1758; Gobius cruentatus Gmelin, 1789; Gobius paganellus Linnaeus, 1758; Parablennius tentacularis (Brünnich, 1768); and Pomatoschistus bathi Miller, 1982.

In contrast to conventional methods, the scuba diving census techniques could improve the knowledge of geographical range and diversity of small gobies (Kovačić and Engin 2009). It is also important to expand usage of technical diving methods in underwater researches in order to investigate deeper habitats and increase bottom time. In this study L. guilleti is reported for the first time in Sea of Marmara that indicates the distribution of this species is larger than known.

\section{ACKNOWLEDGEMENTS.}

This study has been supported by the Scientific and Technological Research Council of Turkey (TÜBİTAK; project No. 112 T 924)

\section{REFERENCES}

Fricke R., Bilecenoglu M., Sari H.M. 2007. Annotated checklist of fish and lamprey species (Gnathostomata and 
Petromyzontomorphi) of Turkey, including a Red List of threatened and declining species. Stuttgarter Beiträge zur Naturkunde, Serie A (Biologie) No. 706.

Golani D., Öztürk B., Başusta N. 2006. Fishes of the eastern Mediterranean. Turkish Marine Research Foundation, Publication No. 24, Istanbul, Turkey.

Kovačić M., Engin S. 2009. First record of the zebra goby, Zebrus zebrus (Gobiidae), in the Black Sea. Cybium 33 (1): 83-84.

Herler J., Kovačić M. 2002. Lebetus guilleti (Teleostei: Gobiidae) in the northern Adriatic Sea: first record and details on the species' morphology. Annales (Series Historia Naturalis) 12: 177-188.

Miller P.J. 1986. Gobiidae. Pp. 1019-1085. In: Whitehead P.J.P., Bauchot M.-L., Hureau J.-C., Nielsen J., Tortonese E. (eds.) Fishes of the North-eastern Atlantic and the Mediterranean. Vol. 3. UNESCO, Paris.
Miller P.J. 1990. Gobiidae. Pp. 925-951. In: Quero J.C., Hureau J.C., Karrer C., Post A., Saldanha L. (eds.) Check-list of the fishes of the eastern tropical Atlantic (CLOFETA). Vol. 2. JNICT, Lisbon, SEI, Paris; and UNESCO, Paris.

Hope R., Shucksmith R. 2010. Most northerly record of Europe's smallest marine fish Guillet's goby Lebetus guilleti in the Shetland Islands, Scotland. Marine Biodiversity Records 3: e98.

DOI: $10.1017 / \mathrm{S} 175526721000103 \mathrm{X}$

Received: 21 July 2014 Accepted: 25 December 2014 Published electronically: 31 March 2015 